\title{
Urinary tract in schoolgirls with covert bacteriuria
}

\author{
M. S. F. McLACHLAN, S. T. MELLER,† E. R. VERRIER JONES, A. W. ASSCHER, \\ E. W. L. FLETCHER, R. T. MAYON-WHITE, J. G. G. LEDINGHAM, J. C. SMITH, \\ and H. H. JOHNSTON \\ From the Departments of Diagnostic Radiology, Child Health, and Medicine, Welsh National School of \\ Medicine, Cardiff; and the Departments of Diagnostic Radiology, Medicine, and Surgery, United Oxford \\ Hospitals, and Public Health Laboratory, Oxford
}

\begin{abstract}
McLachlan, M. S. F., Meller, S. T., Verrier Jones, E. R., Asscher, A. W., Fletcher, E. W. L., Mayon-White, R. T., Ledingham, J. G. G., Smith, J. C., and Johnston, H. H. (1975). Archives of Disease in Childhood, 50, 253. Urinary tract in schoolgirls with covert bacteriuria. During screening of 16800 primary schoolgirls, aged 4-12 years, in Cardiff and Oxford, significant bacteriuria was found in $294(1 \cdot 7 \%)$. Intravenous urography and micturating cystography were performed in 246 of these girls. The urinary tract was abnormal in $47 \%$. Pyelonephritis with or without vesicoureteric reflux was present in $26 \%$ and reflux without renal abnormality in a further $16 \%$. The prevalence of pyelonephritis and reflux was independent of age. With few exceptions kidneys without pyelonephritic scars appeared to be normal in size, even when ureteric reflux was present.
\end{abstract}

Covert bacteriuria, which describes significant bacteriuria (Kass, 1956) detected by a screening programme (Kunin, Deutscher, and Paquin, 1964), occurs in $1-2 \%$ of young schoolgirls (Kunin et al., 1964; Savage et al., 1969; Meadow, White, and Johnston, 1969). We present the radiological observations in the urinary tract in 246 schoolgirls aged 4-12 years with covert bacteriuria in Cardiff and Oxford. These observations will form a basis on which to assess change during the next 4 years.

\section{Patients and methods}

Techniques used to screen primary schoolgirls aged 4-12 years in Cardiff and Oxford for significant bacteriuria are described elsewhere (Asscher et al., 1973b). Of 16800 girls tested, $294(1 \cdot 7 \%)$ showed significant bacteriuria, defined as more than $10^{5}$ organisms $/ \mathrm{ml}$ urine (Kass, 1956) in at least two consecutive midstream specimens. Intravenous urography and micturating cystography were performed in 246 of these bacteriuric children; 180 were examined in Cardiff, 66 in Oxford. Both examinations were performed on the same afternoon, nearly always by the same teams of radiologist, radiographers, and nurses. Parents were advised to give their child a light breakfast on the morning of the examinations and to discourage her from drinking, and

Received 24 September 1974.

Present addresses: ${ }^{\star}$ Department of Radiodiagnosis, University of Leeds.

tQueen Mary's Hospital for Children, Carshalton, Surrey. also to give her a laxative on the two evenings immediately before the examinations.

Micturating cystography was performed first. The child was placed on a tilting $x$-ray table. The bladder was catheterized (4.5-9 FG catheter) and drained. This urine was cultured at once. A control film of the bladder area was taken, using $70 \mathrm{~mm}$ film in Cardiff and a conventional $x$-ray in Oxford. Sterile sodium or meglumine diatrizoate containing approximately $150 \mathrm{mg}$ iodine $/ \mathrm{ml}$ was allowed to run into the bladder under gravity from a height of $100-120 \mathrm{~cm}$. While the bladder filled it was screened intermittently at $0 \cdot 25-0.5$ $\mathrm{mA}$ and $60-80 \mathrm{kV}$. Any abnormality was $x$-rayed, particularly the upper extent of any ureteric reflux. When the child was ready to urinate, the table was tilted. In Cardiff, the table was placed vertical, the child was turned into the lateral or, more commonly, a steep oblique position, the catheter was removed and the child allowed to urinate into a funnel-mouthed container placed between her thighs. Micturition was intermittently recorded at 3 frames/s at $0.03 \mathrm{~mA}$ and $100-120$ $\mathrm{kV}$ using $70 \mathrm{~mm}$ film (Kaude and Reed, 1969). In Oxford, the table was tilted $20^{\circ}$ to the feet and micturition was recorded on a spot-film device with the child supine (Edwards, 1972). Again, the upper extent of any reflux was recorded. Intravenous urography was then performed. Technique in the two cities was identical. This consisted of a full-length control $x$-ray, $x$-rays of the renal area, 3 and $8 \mathrm{~min}$ after intravenous injection of $1.25 \mathrm{ml} / \mathrm{kg}$ bodyweight of sodium and meglumine diatrizoate (Urovison), and a full length $x$-ray at $12 \mathrm{~min}$. Examinations were conducted on a 
standard Bucky table with a tomographic attachment at $100 \mathrm{~cm}$ FFD, 60-90 mA, and 60-65 kV. Abdominal compression was not used. Examinations were monitored by a radiologist and further views obtained if necessary. Tomography was rarely required. Measures were taken to minimize radiation to the ovaries.

Renal length was measured, usually on the 3-min film. Pyelonephritis was defined according to Hodson (1968) and included kidneys showing a discrepancy in length of more than $15 \mathrm{~mm}$ in the absence of unilateral duplex (Stolpe, King, and White, 1967), even if no scarring was present. In cases of unilateral disease, the opposite kidney was considered to show compensatory hypertrophy if its length exceeded by more than $5 \mathrm{~mm}$ the distance between the superior border of the first lumbar vertebra and the inferior border of the fourth, including intervening discs (Stolpe et al., 1967). Grading of vesicoureteric reflux conformed to the criteria of other authors (Smellie, 1967; Rolleston, Shannon, and Utley, 1970). In grade 1 reflux was confined to the ureter; in grade 2 it reached calyces without distending them; in grade 3 it produced calyceal distension. Ureteric dilatation was judged subjectively on intravenous urograms.

\section{Results}

Of the 246 children $47 \%$ had an abnormal urinary tract (Fig. 1). Pyelonephritis with or

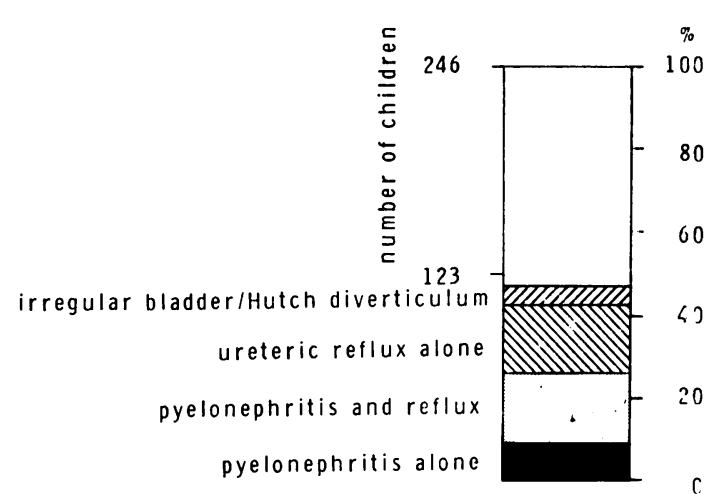

FIG. 1.-Prevalence of abnormality of the urinary tract in primary schoolgirls with covert bacteriuria. For definition of pyelonephritis and Hutch diverticulum, see text.

without vesicoureteric reflux was observed in $26 \%$; reflux without renal abnormality occurred in a further $16 \%$. Catheter specimens of urine were negative in $20 \%$ of bacteriuric children. The prevalence of abnormality ( $42 \%$ ) was similar in this subgroup. Fig. 2. indicates renal lengths in child-

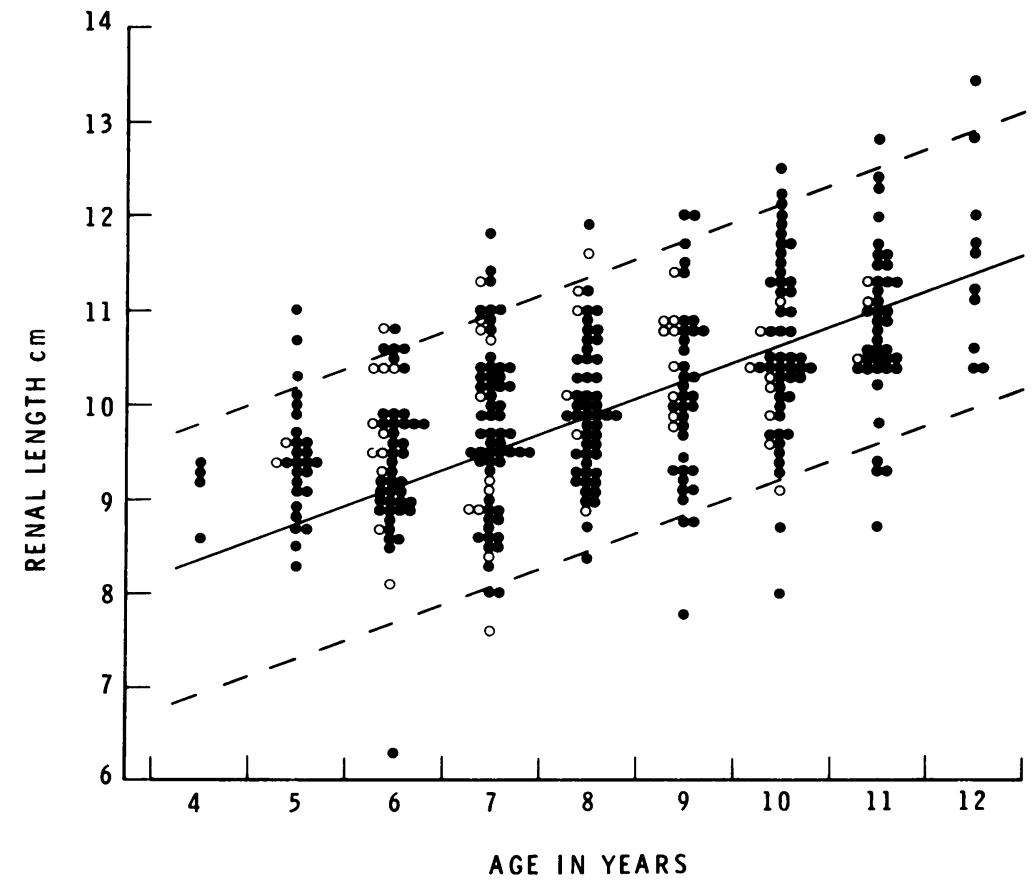

FIG. 2.-Renal lengths in children without scarred or duplex kidneys. Kidneys drained by ureters without reflux O; kidneys drained by ureters with reflux $\bigcirc$; mean renal length for normal children $-; \pm 1 S D$ (Hodson et al., 1962) --- . 
ren without scarring or duplex kidneys. They are close to the mean value found by Hodson et al. (1962) in 'normal' children. Kidneys drained by refluxing ureters do not differ from the rest. In 5 children, the lengths of the two unscarred kidneys differed by more than $15 \mathrm{~mm}$. This was interpreted as pyelonephritis (see Patients and methods). Fig. 3 indicates renal lengths in children with scarring. 8 kidneys were considered to show evidence of compensatory hypertrophy when compared with vertebral height. Scarred kidneys tended to be small. 7 showed widespread loss of renal substance (mean length $6.5 \mathrm{~cm}$ ); 20 were scarred in two or more sites. Scarring affected the upper pole twice as often as the lower pole and nearly three times more often than the midportion. 6 kidneys showed polar scars without calyceal deformity. Scars were bilateral in 14 children. The prevalence of scarring at each age was similar (Fig. 4); its extent also did not change with age.

Fig. 5 shows the prevalence of pyelonephritis for each grade of vesicoureteric reflux. Pyelonephritis is more common when reflux is severe. No clear association existed between the extent of scarring and the severity of reflux. However, 4 of the 7 kidneys with widespread loss of renal substance were drained by ureters showing grade 3 reflux. In 4 children unilateral scarring existed on the side opposite to that of reflux. Reflux was bilateral in 28 children and unilateral in 54 , with no significant difference between the two sides. Unilateral reflux tended to be less severe. Neither the prevalence nor grade of reflux was related to age (Fig. 6). The slightly lower prevalence in 11-year-old children is not significant. Bilateral reflux was equally common at each age. Intrarenal reflux (Hodson, 1969; Rolleston et al., 1970) was not observed. Of 18 dilated ureters, 4 which drained scarred kidneys showed no reflux. Severe reflux occurred in all 3 ureters with longitudinal striations on intravenous urograms (Gwinn and Barnes, 1964; Silber and McAlister, 1970). Reflux was noted in 7 out of 14 duplex systems and in 6 out of 11 children with vesicoureteric diverticula (Hutch, 1961a). Irregularity of the bladder wall existed as an isolated abnormality in 11 children, presumably due to inflammation. The bladder neck was normal in all children studied.

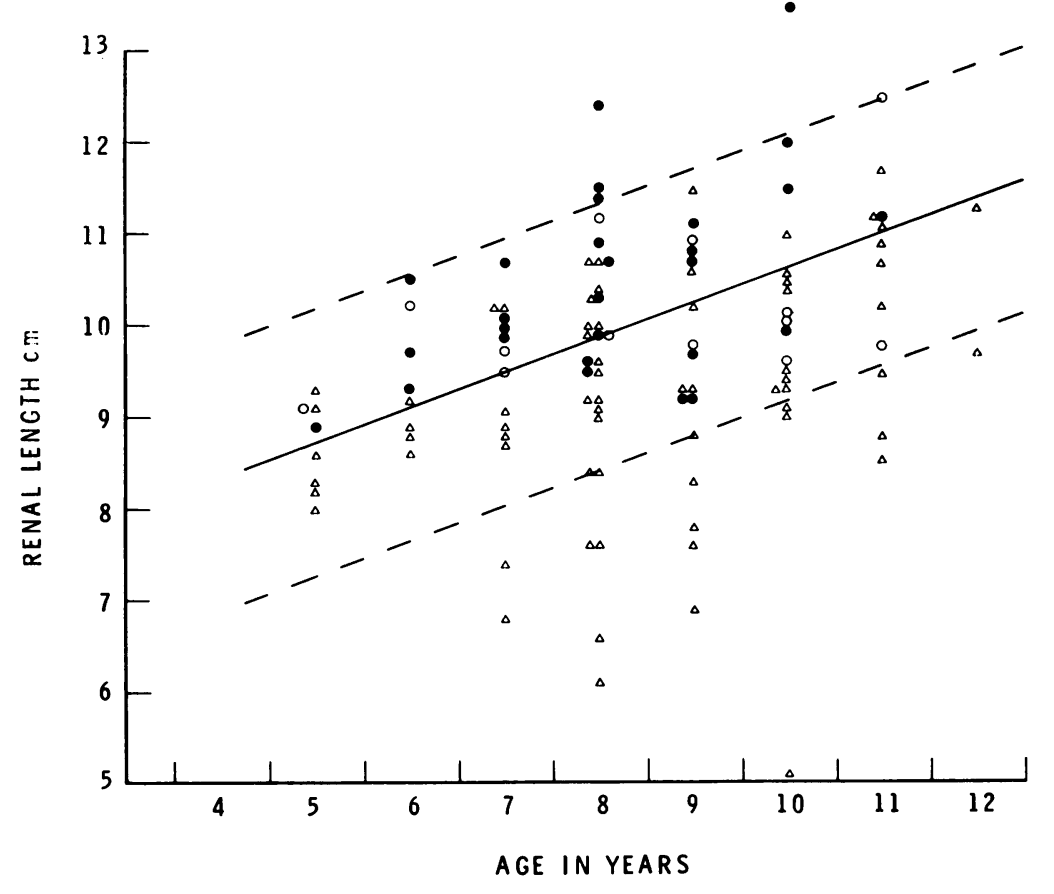

FIG. 3.-Renal lengths in children with scarred, nonduplex kidneys. Scarred kidneys $\triangle$; contralateral unscarred kidneys drained by ureters without reflux - ; contralateral unscarred kidneys drained by ureters with reflux 0 ; mean renal length for normal children -; $11 S D$ (Hodson et al., 1962) - - . 


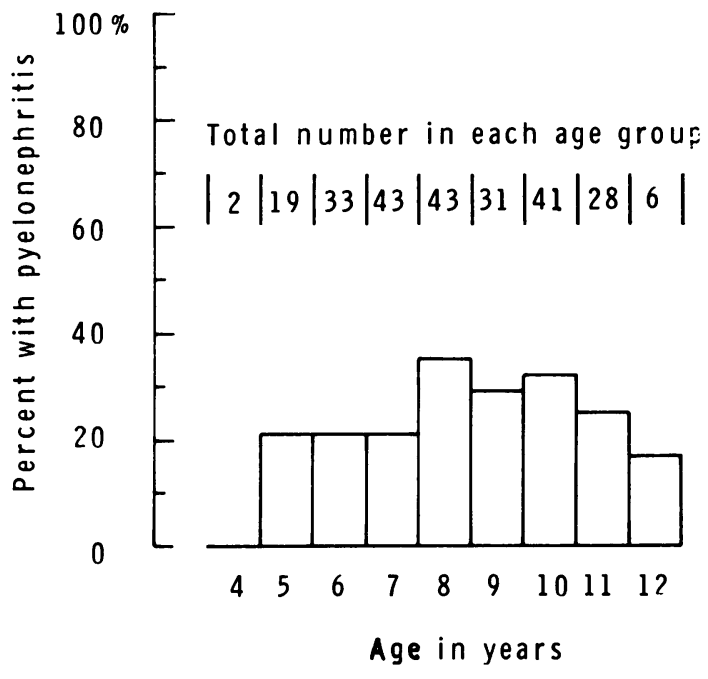

FIG. 4.-Prevalance of pyelonephritis in each age group.

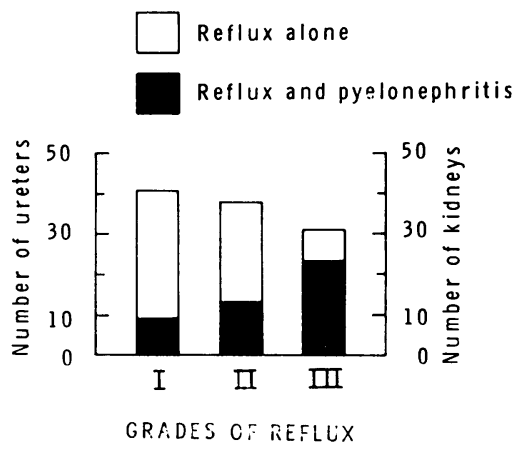

FIG. 5.-Prevalence of pyelonephritis at each grade of vesicoureteric reflux (defined in text).

\section{Discussion}

The prevalence of covert bacteriuria $(1 \cdot 7 \%)$ in primary schoolgirls in Cardiff and Oxford resembles that observed elsewhere in this country (Savage et al., 1969; Meadow et al., 1969) and the United States (Kunin et al., 1964). We confirm the findings of Savage et al. (1973) that radiological examination of schoolgirls with covert bacteriuria detects abnormality of the urinary tract in nearly $50 \%$. Like them, we showed vesicoureteric reflux in one-third and pyelonephritic scarring in one-quarter. The prevalence of abnormality is the same in children in whom urinary tract infection has declared itself (Smellie et al., 1964). We found bilateral abnormality in $22 \%$ of children with pyelonephritic kidneys. One-third of these kidneys

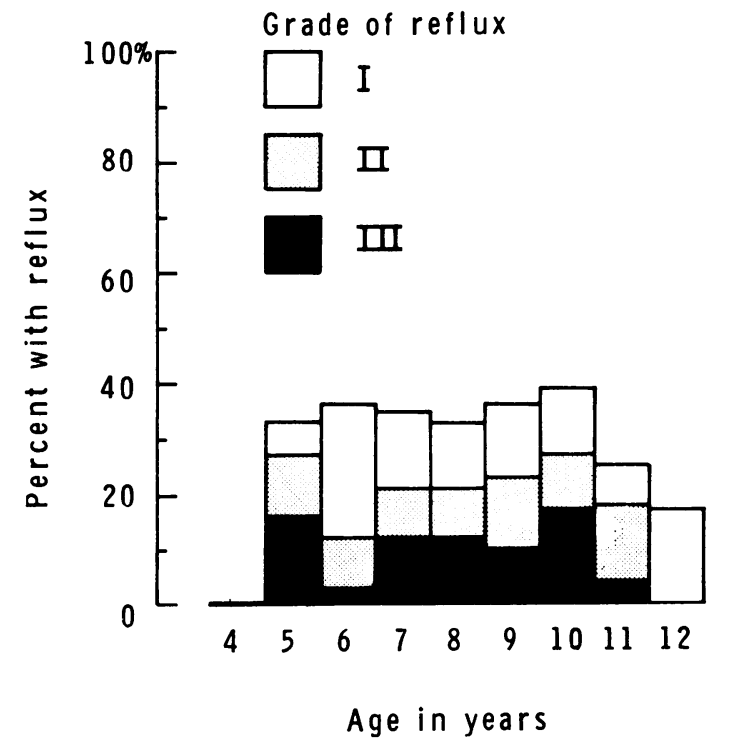

FIG. 6.-Grade and prevalence of reflux in each age group.

showed extensive disease, being markedly shrunken or scarred in more than one site. The upper pole was most frequently involved, as Hodson (1968) observed. Like him, we occasionally saw scars with little or no calyceal deformity. The earliest lesion, in his view, is retarded growth of one kidney. However, we seldom noted unscarred kidneys which were asymmetrical in length and few showed compensatory hypertrophy. The length of the normal adult kidney is well correlated with its post-mortem weight (Griffiths, Cartwright, and McLachlan, 1975) and it is likely that the same is true in childhood (Hodson et al., 1962). Though it has been said (Smellie et al., 1964; Smellie, 1967) that sterility of the urine is necessary to prevent scarring and to allow kidneys to grow normally, we did not find that older children with bacteriuria had small kidneys or a greater prevalence of scarring, even if reflux was present. Serial studies (McRae, Shannon, and Utley, 1974) also suggest that moderate reflux does not restrict renal growth.

Our observations are consistent with those of Hodson (1968) that scarring usually appears in the first few years of life. Hodson's view (1969), endorsed by Bailey (1973), is that scarring is initiated by reflux of urine into the substance of the kidney. This has been noted in the immature kidney of infants (Rolleston et al., 1970), piglets (Hodson, 1974), and rats (M. Morgan and A. W. Asscher, in preparation). Our failure to observe intrarenal reflux may be due to the age of the child- 
ren whom we examined (Rolleston, Maling, and Hodson, 1974). We agree with Maling and Rolleston (1974) that its demonstration requires careful technique. The diagnosis of straightforward vesicoureteric reflux may not require elaborate radiological methods. Savage et al. (1973), whose simple technique of cystography consisted of 3 $x$-rays without flouroscopic screening, observed reflux as often as we did. Occasionally, severe reflux may be suggested by ureteric striations visible at intravenous urography (Gwinn and Barnes, 1964; Silber and McAlister, 1970). Frequently the upper urinary tract appears normal (Hutch, Miller, and Hinman, 1963). We would have missed many examples of reflux had we followed a policy, proposed by Bailey (1973), of avoiding cystography in children over 5 years old with a normal excretion urogram. One child in 4 in whom reflux was gross enough to distend calyces showed no renal lesion at excretion urography. Though we noted no significant decrease in the prevalence of reflux with age, serial studies during long-term chemotherapy (Stephens, 1963; Smellie, 1967; Rolleston et al., 1970) have found that reflux tends to become less severe with time and may remit completely. It is likely that remission results from maturation of the vesicoureteric junction (Hutch, 1961b). This would explain the existence of dilated ureters or vesicoureteric diverticula, abnormalities associated with reflux (Hutch, 1961a; Stephens, 1963) in children in whom no reflux was shown. However, remission may not occur, even in adults. Williams et al. (1968) found reflux in $21 \%$ of women in whom bacteriuria had been detected during a previous pregnancy.

Studies of the point prevalence of abnormalities of the urinary tract can give only limited information on the effects of covert bacteriuria. Though we revealed much unsuspected disease, we consider that the value of screening schoolgirls for bacteriuria is still undecided. Our observation that many children, including those with an abnormal urinary tract, had sterile catheter specimens of urine emphasizes that bacteriuria is not a stable condition which can be detected in a single survey. Covert bacteriuria puts children at risk of developing frank urinary tract infections in later life (Kunin, 1971), but appears not to produce progressive renal disease in adult females (Asscher et al., 1973a). Further longitudinal studies are required to define any relation which may exist in childhood between bacteriuria and progressive renal damage. The results presented here form part of such a study and will be compared with later radiological observations. Our present measurements of unscarred kidneys do not, in general, indicate failure of renal growth; the distribution of pyelonephritis with age suggests that scarring occurred before these children entered school. Attempts to prevent renal damge should probably be directed towards children of preschool age. The feasibility of screening children of this age for bacteriuria has recently been shown (Davies et al., 1974).

We acknowledge help received from nurses and radiographers in both cities, and are especially grateful to Mrs. J. Kidd, Mrs. M. Dawes, Mrs. D. Haddock, Mr. C. Latto, and Mr. and Mrs. E. Roberts. Invaluable help was also provided by Miss P. Mannings and Mrs. M. Morgan. Mr. G. Draper gave statistical advice. The study was conducted with the co-operation of Drs. Gillian Sleight and E. Smith. Financial help was received from the Dr. Clark Memorial Fund, Reading, and the Kidney Research Foundation for Wales.

\section{REFERENCES}

Asscher, A. W., Chick, S., Radford, N., Waters, W. E., Sussman, M., Evans, J. S., McLachlan, M. S. F., and Williams, J. E. (1973a). Natural history of asymptomatic bacteriuria (ASB) in non-pregnant women. Urinary Tract Infection, p.51. Ed. by W. Brumfitt and A. W. Asscher. Oxford University Press, London.

Asscher, A. W., McLachlan, M. S. F., Verrier Jones, R., Meller, S., Sussman, M., Harrison, S., Johnston, H. H., Sleight, G., and Fletcher, E. W. (1973b). Screening for asymptomatic urinary-tract infection in schoolgirls. Lancet, 2,1 .

Bailey, R. R. (1973). The relationship of vesico-ureteric reflux to urinary tract infection and chronic pyelonephritis-reflux nephropathy. Clinical Nephrology, 1, 132.

Davies, J. M., Gibson, G. L., Littlewood, J. M., and Meadow, S. R. (1974). Prevalence of bacteriuria in infants and preschool children. Lancet. 2, 7.

Edwards, D. (1972). Cystography. Practical Procedures in Diagnostic Radiology, 2nd ed., p. 54. Ed. by H. M. Saxton and B. Strickland. Lewis, London.

Griffiths, G. J., Cartwright, G., and McLachlan, M. S. F. (1975). Estimation of renal size from radiographs: is the effort worthwhile? Clinical Radiology. (In the press.)

Gwinn, J. L., and Barnes, G. R. (1964). Striated ureters and renal pelves. American fournal of Roentgenology, 91, 666.

Hodson, C. J. (1968). Radiological diagnosis of renal involvement. Urinary Tract Infection, p. 108 . Ed. by F. O'Grady and W. Brumfitt. Oxford University Press, London.

Hodson, C. J. (1969). The effects of disturbance of flow on the kidney. Fournal of Infectious Diseases, 120, 54.

Hodson, C. J. (1974). Vesico-ureteric reflux and renal scarringwith and without infection. (Abst.). Kidney International, 5, 308.

Hodson, C. J., Drewe, J. A., Karn, M. N., and King, A. (1962). Renal size in normal children. Archives of Disease in Childhood, 37, 616.

Hutch, J. A. (1961a). Saccule formation at the ureterovesical junction in smooth walled bladders. Fournal of Urology, 86, 390.

Hutch, J. A. (1961b). Theory of maturation of the intravesical ureter. Fournal of Urology, 86, 534.

Hutch, J. A., Miller, E. R., and Hinman, F. (1963). Vesicoureteral reflux. American fournal of Medicine, 34, 338.

Kass, E. H. (1956). Asymptomatic infections of the urinary tract. Transactions of the Association of American Physicians, 69, 56.

Kaude, J. V., and Reed, J. M. (1969). Voiding urethrocystography by means of 70-mm image-intensifier fluorography. Radiology, 92, 768.

Kunin, C. M. (1971). Epidemiology and natural history of urinary tract infection in school age children. Pediatric Clinics of North America, 18, 509. 
Kunin, C. M., Deutscher, R., and Paquin, A. (1964). Urinary tract infection in school children: an epidemiologic, clinical and laboratory study. Medicine, 43,91 .

McRae, C. U., Shannon, F. T., and Utley, W. L. F. (1974). Effect on renal growth of reimplantation of refluxing ureters. Lancet, $1,1310$.

Maling, T. M. J., and Rolleston, G. L. (1974). Intrarenal reflux in children demonstrated by micturating cystography. Clinical Radiology, 25, 81.

Meadow, S. R., White, R. H. R., and Johnston, N. M. (1969). Prevalence of symptomless urinary tract disease in Birmingham schoolchildren. I. Pyuria and bacteriuria. British Medical Fournal, 3, 81.

Rolleston, G. L., Maling, T. M. J., and Hodson, C. J. (1974). Intrarenal reflux and the scarred kidney. Archives of Disease in Childhood, 49, 531.

Rolleston, G. L., Shannon, F. T., and Utley, W. L. F. (1970). Relationship of infantile vesicoureteric reflux to renal damage. British Medical fournal, 1, 460.

Savage, D. C. L., Wilson, M. I., Ross, E. M., and Fee, W. M. (1969). Aysmptomatic bacteriuria in girl entrants to Dundee primary schools. British Medical fournal, 3, 75.
Savage, D. C. L., Wilson, M. I., McHardy, M., Dewar, D. A. E., and Fee, W. M. (1973). Covert bacteriuria of childhood. Archives of Disease in Childhood, 48, 8.

Silber, I., and McAlister, W. H. (1970). Longitudinal folds as an indirect sign of vesicoureteral reflux. Fournal of Urology, $103,89$.

Smellie, J. M. (1967). Medical aspects of urinary infection in children. Fournal of the Royal College of Physicians, 1, 189.

Smellie, J. M., Hodson, C. J., Edwards, D., and Normand, I. C. S. (1964). Clinical and radiological features of urinary infection in childhood. British Medical fournal, 2, 1222.

Stephens, F. D. (1963). Clinical features and prognosis of vesicoureteral reflux. Fournal of the College of Radiologists of Australasia, 7, 17.

Stolpe, Y., King, L. R., and White, H. (1967). The normal range of renal size in children. Investigative Urology, 4, 600.

Williams, G. L., Davies, D. K. L., Evans, K. T., and Williams, J. E. (1968). Vesicoureteric reflux in patients with bacteriuria in pregnancy. Lancet, 2, 1202.

Correspondence to Dr. A. W. Asscher, K.R.U.F. Institute of Renal Disease, Royal Infirmary, Cardiff. 